\title{
Energy and Environmental Research Emphasizing Low-Rank Coal -- Task 1.7 Hot-Water Extraction of Nonpolar Organic Pollutants from Soils
}

\section{Topical Report}

Steven B. Hawthorne

January 1995

Work Performed Under Contract No.: DE-FC21-93MC30097

For

U.S. Department of Energy

Office of Fossil Energy

Morgantown Energy Technology Center

Morgantown, West Virginia

By

University of North Dakota Grand Forks, North Dakota 


\section{DISCLAIMER}

This report was prepared as an account of work sponsored by an agency of the United States Government. Neither the United States Government nor any agency thereof, nor any of their employees, makes any warranty, express or implied, or assumes any legal liability or responsibility for the accuracy, completeness, or usefulness of any information, apparatus, product, or process disclosed, or represents that its use would not infringe privately owned rights. Reference herein to any specific commercial product, process, or service by trade name, trademark, manufacturer, or otherwise does not necessarily constitute or imply its endorsement, recommendation, or favoring by the United States Government or any agency thereof. The views and opinions of authors expressed herein do not necessarily state or reflect those of the United States Government or any agency thereof.

This report has been reproduced directly from the best available copy.

Available to DOE and DOE contractors from the Office of Scientific and Technical Information, 175 Oak Ridge Turnpike, Oak Ridge, TN 37831; prices available at (615) 576-8401.

Available to the public from the National Technical Information Service, U.S. Department of Commerce, 5285 Port Royal Road, Springfield, VA 22161; phone orders accepted at (703) 487-4650. 
罢

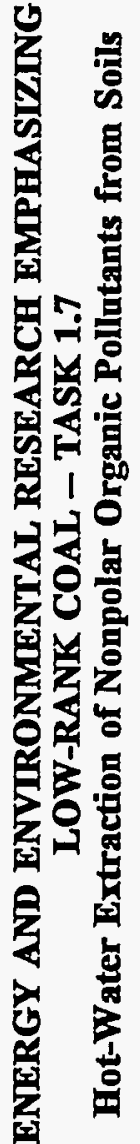

令 


\title{
Energy and Environmental Research Emphasizing Low-Rank Coal -- Task 1.7 Hot-Water Extraction of Nonpolar Organic Pollutants from Soils
}

\section{Topical Report}

Steven B. Hawthorne

Work Performed Under Contract No.: DE-FC21-93MC30097

For

U.S. Department of Energy

Office of Fossil Energy

Morgantown Energy Technology Center

P.O. Box 880

Morgantown, West Virginia 26507-0880

\author{
By \\ University of North Dakota \\ Energy and Environmental Research Center \\ P.O. Box 9018 \\ Grand Forks, North Dakota 58202-9018
}

January 1995 


\section{ACKNOWLEDGMENT}

This semiannual was prepared with the support of the U.S. Department of Energy (DOE) Morgantown Energy Technology Center Cooperative Agreement No. DE-FC21-93MC30097.

However, any opinions, findings, conclusions, or recommendations expressed herein are those of the author(s) and do not necessarily reflect the views of the DOE. 


\section{TABLE OF CONTENTS}

LIST OF TABLES $\ldots \ldots \ldots \ldots \ldots \ldots \ldots \ldots \ldots \ldots \ldots \ldots \ldots \ldots \ldots \ldots \ldots \ldots$ ii

EXECUTIVE SUMMARY $\ldots \ldots \ldots \ldots \ldots \ldots \ldots \ldots \ldots \ldots \ldots \ldots$

1.0 INTRODUCTION $\ldots \ldots \ldots \ldots \ldots \ldots \ldots \ldots \ldots \ldots \ldots \ldots \ldots \ldots \ldots \ldots \ldots \ldots$

2.0 OBJECTIVES $\ldots \ldots \ldots \ldots \ldots \ldots \ldots \ldots \ldots \ldots \ldots \ldots \ldots \ldots \ldots \ldots \ldots \ldots \ldots \ldots$

3.0 ACCOMPLISHMENTS . . . . . . . . . . . . . . . . . . 2

3.1 Water Extraction Removal Efficiencies of PAHs at Several Temperatures and

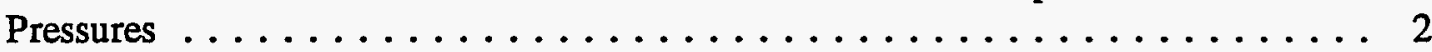

3.2 The Optimized "Mild" Conditions for Obtaining High Extraction Efficiencies . . . . 3

3.3 Solubility Enhancement of PAHs in Subcritical Water ............. 3

3.4 Removal of PCBs from Soil and Sediment at Optimal Extraction Conditions ..... 4 


\section{LIST OF TABLES}

1 Minimum Enhancement in PAH Solubility in Subcritical Water . . . . . . . . . . . 4

2 PCB Removal from Soil and Sediment Using Water Extractions at

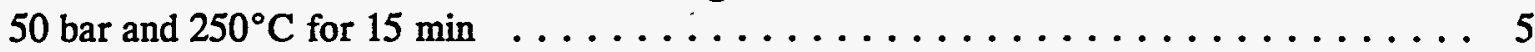




\section{SUBTASK 1.7 HOT-WATER EXTRACTION OF NONPOLAR ORGANIC POLLUTANTS FROM SOILS}

\section{EXECUTIVE SUMMARY}

Supercritical water extraction of organic pollutants from solids is extremely effective because supercritical water has a low dielectric constant and can, therefore, efficiently solvate organics. However, the decrease in the dielectric constant of water can be achieved at much milder conditions (pressures of a few bar and temperatures of ca. $200^{\circ}-250^{\circ} \mathrm{C}$ ) than the conditions used for supercritical water (pressure $>221$ bar and temperature $>374^{\circ} \mathrm{C}$ ) extractions. Polycyclic aromatic hydrocarbons (PAHs) were extracted from a highly contaminated soil using water at temperatures ranging from $50^{\circ}$ to $400^{\circ} \mathrm{C}$, and pressures from 5 to 600 bar. Most PAHs could not be extracted at $50^{\circ} \mathrm{C}$ but were completely removed at a temperature of $250^{\circ} \mathrm{C}$. Additional increases to $300^{\circ} \mathrm{C}$ (still subcritical conditions) and $400^{\circ} \mathrm{C}$ (supercritical water) did not increase the recoveries significantly. The removal of PAHs had very little dependence on pressure when the temperature was $250^{\circ} \mathrm{C}$, except that steam extraction (at 5 bar) yielded lower recoveries than the liquid water extractions (at 50,350 , and 600 bar). Therefore, the optimal conditions for extracting PAHs using water were 50 bar and $250^{\circ} \mathrm{C}$ (hot water). Based on the extraction rates obtained for several of the PAHs, the solubility of high molecular weight PAHs increased at least several thousandfold by increasing the water temperature to $200^{\circ}-300^{\circ} \mathrm{C}$.

Polychlorinated biphenyls (PCBs) were extracted from an industry soil and a sediment using hot-water (subcritical) extraction at 50 bar and $250^{\circ} \mathrm{C}$. Although the PCB concentration in the sediment was nearly a thousand times lower than that in the industry soil, all the individual PCB congeners studied were quantitatively removed from both samples. The high removal efficiencies of PCBs from soil and sediment agree very well with those obtained for PAHs from highly contaminated soil at the same extraction conditions, demonstrating that water is a potentially useful extraction solvent for many organics. 


\subsection{INTRODUCTION}

While water is an environmentally acceptable solvent, it has not yet received attention as a subcritical extraction solvent for environmental solids because water is too polar (at ambient conditions) to efficiently dissolve most of the nonionic organics associated with environmental solids.

At ambient temperature and pressure, water has a dielectric constant $(\epsilon)$ of ca. 80 (polar), but the dielectric constant is decreased to ca. 8 (nonpolar) in steam or supercritical water conditions (temperature $>374^{\circ} \mathrm{C}$ and pressure $>221$ bar). Therefore, water has been used to extract soils contaminated with organic pollutants either by steam stripping or under supercritical conditions. Both techniques are severely limited for environmental remediation, i.e., steam stripping is only effective on relatively volatile organics, and the high-corrosivity, high-temperature, and high-pressure requirements of supercritical water makes its use unrealistic.

However, the conditions that make supercritical water effective (e.g., lowering of the water's dielectric constant so that it behaves like an organic solvent) do not require supercritical conditions, and can be achieved at relatively "engineering-friendly" conditions of only a few atmospheres of pressure and temperatures as low as $200^{\circ}-250^{\circ} \mathrm{C}$. Surprisingly, these mild conditions have not been investigated as a remediation technique. Preliminary studies in our laboratory using water at $50 \mathrm{~atm}$ and $250^{\circ} \mathrm{C}$ have shown nearly quantitative removal of creosote polycyclic aromatic hydrocarbons (PAHs) from a highly contaminated soil. This study determined the feasibility of subcritical water to extract nonpolar organic pollutants, such as PAHs and polychlorinated biphenyls (PCBs), from contaminated soils and sediments.

\subsection{OBJECTIVES}

The objective was to determine the ability of hot water (subcritical water) to extract PAHs and PCBs from contaminated soils. Specific objectives were:

- Determine the optimal pressure and temperature for removal of PAHs from real-world contaminated soils.

- Determine the minimum pressure and temperature required for reasonable removal rates of PAHs.

- Perform preliminary determinations of the use of hot (subcritical) water to remove other organic contaminants, i.e., PCBs from contaminated soils and sediments.

\subsection{ACCOMPLISHMENTS}

\subsection{Water Extraction Removal Efficiencies of PAHs at Several Temperatures and Pressures}

The effects of water temperature (at a constant pressure of $350 \mathrm{bar}$ ) on the extraction of PAHs from a highly contaminated soil (purchased from Fisher Scientific) are summarized in Table 2 in the attached publication (Appendix). As would be expected on the basis of the high dielectric constant of 
water, extractions at $50^{\circ} \mathrm{C}$ failed to yield significant recovery of any of the PAHs. As the temperature was increased to $200^{\circ} \mathrm{C}$, the removal of all the PAHs increased substantially. Further increases in removal were achieved by increasing the temperature to $250^{\circ} \mathrm{C}$, and the recoveries at $250^{\circ} \mathrm{C}$ compared very favorably with the certified concentrations. Additional increases to $300^{\circ} \mathrm{C}$ (still subcritical conditions) and $400^{\circ} \mathrm{C}$ (supercritical water) did not increase the recoveries significantly despite lowering the dielectric constant to about 22 and 8 , respectively.

Because the dielectric constant of water depends primarily on temperature and much less on the pressure (Figure 1 in the attached publication, see Appendix), the removal of PAHs had very little dependence on pressure (as shown in Table 3 in the attached publication, see Appendix) when the temperature was $250^{\circ} \mathrm{C}$. However, steam extraction (at 5 bar) yielded lower recoveries than the liquid water extractions (at 50, 350, and 600 bar).

\subsection{The Optimized "Mild" Conditions for Obtaining High Extraction Efficiencies}

As discussed above, the optimal pressure and temperature for removal of PAHs from realworld contaminated soils were 50 bar and $250^{\circ} \mathrm{C}$. The optimal condition could be even "milder" (lower) for obtaining the same (high) extraction efficiencies if longer extraction times are used. As shown in Table 2 in the Appendix, the extraction at $200^{\circ} \mathrm{C}$ for $15 \mathrm{~min}$ yielded low recoveries of high molecular weight PAHs. However, when the extraction time was increased to $60 \mathrm{~min}$, the removal of all PAHs was as high as those obtained at $250^{\circ} \mathrm{C}$ (see Figure 3 in the Appendix). Therefore, the lowest (mildest) extraction temperature to quantitatively remove PAHs from contaminated soils is $200^{\circ} \mathrm{C}$ if the extraction is performed for $60 \mathrm{~min}$.

Figure 1 in the Appendix shows the pressure-temperature diagram of water. For the extractions at $250^{\circ} \mathrm{C}$, the minimum pressure required to keep water as a liquid (not steam) is ca. 30 bar. Based on the results in Table 2 in the attached publication (see Appendix), any pressure that can keep hot water as a liquid could give almost the same removal of PAHs. Therefore, the lowest pressure for the extractions at $250^{\circ} \mathrm{C}$ is ca. 30 bar. When the extractions are performed at $200^{\circ} \mathrm{C}$, the minimum pressure could be decreased to ca. 12 bar (still keeping water in liquid condition).

\subsection{Solubility Enhancement of PAHs in Subcritical Water}

The PAH solubility in ambient water is very low, on the order of $\mathrm{ppm}$ to $\mathrm{ppb}$ concentrates. However, the solubilities could be dramatically increased by increasing the water temperature (lowering the dielectric constant of water). The minimum enhancement in solubility was calculated based on the quantity of each individual PAH in the contaminated soil that was extracted under the various subcritical water conditions. This enhancement factor is very conservative, because we were extracting a real-world sample, and thus, the amounts of PAHs were limited. If larger quantities of PAHs, or if pure PAHs, were available, the enhancement in solubility would be even larger.

As shown in Table 1, the solubilities of the high-molecular-weight PAHs in subcritical water are increased by at least three orders of magnitude by simply increasing the temperature. This enhancement in solubility should apply to organics that have low solubilities in ambient water (e.g., PCBs and most fuel hydrocarbons). 
Minimum Enhancement in PAH Solubility in Subcritical Water

\begin{tabular}{|c|c|c|c|c|c|}
\hline \multirow[b]{2}{*}{$\mathrm{PAH}$} & \multirow[b]{2}{*}{$\begin{array}{l}\text { Conc. In Soil, } \\
\mathrm{mg} / \mathrm{kg}\end{array}$} & \multirow[b]{2}{*}{$\begin{array}{l}\text { PAH Solubility, } \\
\mathrm{mg} / \mathrm{L}\left(1 \mathrm{bar}, 20^{\circ} \mathrm{C}\right)\end{array}$} & \multicolumn{3}{|c|}{$\begin{array}{l}\text { Minimum Enhancement in PAH Solubility } \\
\qquad 350 \text { bar }\end{array}$} \\
\hline & & & $120^{\circ} \mathrm{C}$ & $200^{\circ} \mathrm{C}$ & $300^{\circ} \mathrm{C}$ \\
\hline Anthracene & 425 & 0.07 & 63 & 91 & 500 \\
\hline Fluoranthene & 1300 & 0.26 & 10 & 62 & 400 \\
\hline Pyrene & 960 & 0.14 & 13 & 81 & 511 \\
\hline Chrysene & 310 & 0.002 & 390 & 1160 & 6500 \\
\hline $\begin{array}{l}\text { Benzo[b]- } \\
\text { fluoranthene }\end{array}$ & 160 & 0.001 & 330 & 960 & 7300 \\
\hline
\end{tabular}

Although there are very few solubilities in the literature of organic compounds in subcritical water at elevated temperatures, the few data that have been reported demonstrate that our preliminary interpretations of the solubility enhancement shown in Table 1 are much too conservative. For example, while our preliminary extraction data indicate a minimum solubility increase of ca. 7000 for higher molecular weight PAHs, an earlier report of the solubility of benzo[e]pyrene at $350^{\circ} \mathrm{C}$ (and ca. 100 bar) was 10 wt\% (Sanders, N.D. Ind. Eng. Chem. Fundam. 1986 25,171), which is 20 million times higher than its solubility of ca. $5 \mu \mathrm{g} / \mathrm{L}$ obtained in water at $20^{\circ} \mathrm{C}$.

\subsection{Removal of PCBs from Soil and Sediment at Optimal Extraction Conditions}

Based on the discussions above, the optimal conditions for the extraction of PAHs for $15 \mathrm{~min}$ were 50 bar and $250^{\circ} \mathrm{C}$. These conditions were used to determine the removal of PCBs from an industry soil and a sediment.

As shown in Table 2, the removal of all of the studied individual PCB congeners is quantitative, although the PCB concentration in the sediment is nearly a thousand times lower than that in the industry soil. The high removal efficiencies of PCBs from soil and sediment agrees very well with those obtained for PAHs from the highly contaminated soil at the same extraction conditions as discussed above. Please note that the extraction time used in Table 2 was 15 min. If the extraction time is increased, the extraction temperature and pressure could be even milder (e.g., ca. 12 bar and $200^{\circ} \mathrm{C}$ ).

The results of this report demonstrate that water is a potentially useful extraction solvent for many organics. Subcritical water at mild conditions ( $\leq 50$ bar and $\leq 250^{\circ} \mathrm{C}$ ) could efficiently extract PAHs and PCBs from soils and sediments. 
TABLE 2

PCB Removal from Soil and Sediment Using Water Extractions at 50 bar and $250^{\circ} \mathrm{C}$ for $15 \mathrm{~min}$

\begin{tabular}{|c|c|c|c|c|c|c|}
\hline \multirow[b]{2}{*}{ PCB } & \multicolumn{3}{|c|}{ Soil, CRM 481} & \multicolumn{3}{|c|}{ Sediment, SRM 1939} \\
\hline & $\begin{array}{c}\text { Cert. Conc., } \\
\mu \mathrm{g} / \mathrm{g}\end{array}$ & Removal, \% & RSD, \% ${ }^{b}$ & $\begin{array}{c}\text { Cert. Conc., } \\
\mu \mathrm{g} / \mathrm{g}\end{array}$ & Removal, \% & $\mathrm{RSD}, \%^{\mathrm{b}}$ \\
\hline PCB-28 & 0.34 & $>99$ & 0 & 2.2 & $>99$ & 1 \\
\hline PCB-52 & 3.15 & 98 & 3 & 3.86 & $>99$ & 0 \\
\hline PCB-101 & 37 & 98 & 3 & 0.46 & $>99$ & 0 \\
\hline РCB-118 & 9.4 & 97 & 3 & 0.51 & $>99$ & 0 \\
\hline PCB-149 & 96 & 98 & 3 & & $>99$ & 0 \\
\hline PCB-153 & 136 & 97 & 3 & & $>99$ & 0 \\
\hline PCB-105 & 1.21 & 98 & 3 & & $>99$ & 0 \\
\hline РCB-138 & 95.3 & 97 & 3 & 0.57 & $>99$ & 0 \\
\hline PCB-128 & 8.72 & 97 & 3 & 0.1 & $>99$ & 0 \\
\hline PCB-156 & 7.08 & 96 & 4 & & $>99$ & 0 \\
\hline PCB-180 & 123 & 96 & 6 & 0.16 & $>99$ & 0 \\
\hline PCB-170 & 52 & 93 & 6 & 0.11 & $>99$ & 0 \\
\hline
\end{tabular}

The percentage removed by water for each PCB congener was calculated from the total quantities removed by water followed by methylene chloride sonication (16 hr) of the residues from the water extractions.

b \%RSD was based on triplicate sequential (water followed by methylene chloride) extractions.

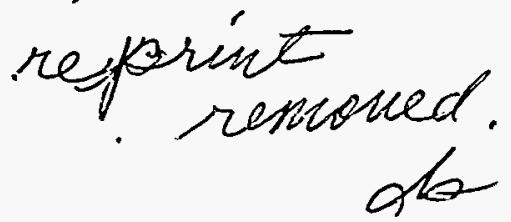


DOE/IIC/30097-5078

\section{Original \\ Camera Ready Copy}

